\title{
Trehangelins A, B and C, novel photo-oxidative hemolysis inhibitors produced by an endophytic actinomycete, Polymorphospora rubra K07-0510
}

\author{
Takuji Nakashima ${ }^{1}$, Ryuki Okuyama ${ }^{2}$, Yoshiyuki Kamiya ${ }^{2}$, Atsuko Matsumoto ${ }^{3}$, Masato Iwatsuki ${ }^{3}$, \\ Yuki Inahashi ${ }^{2,3}$, Kenzaburo Yamaji ${ }^{3}$, Yōko Takahashi, ${ }^{2,3}$ and Satoshi Ōmura ${ }^{3}$
}

Three new natural products, designated trehangelins A, B and C, were isolated by solvent extraction, silica gel and octadecylsilyl silica gel column chromatographies and subsequent preparative HPLC from the cultured broth of an endophytic actinomycete strain, Polymorphospora rubra K07-0510. The trehangelins consisted of a trehalose moiety and two angelic acid moieties. Trehangelins $A\left(\mathrm{IC}_{50}\right.$ value, $\left.0.1 \mathrm{mg} \mathrm{ml}^{-1}\right)$ and $\mathrm{C}\left(\mathrm{IC}_{50}\right.$ value, $\left.0.4 \mathrm{mg} \mathrm{ml}^{-1}\right)$, with symmetric structures, showed potent inhibitory activity against hemolysis of red blood cells induced by light-activated pheophorbide $a$. However, trehangelin $\mathrm{B}$, with an asymmetric structure, displayed only a slight inhibition ( $\mathrm{IC}_{50}$ value, $1.0 \mathrm{mg} \mathrm{ml}^{-1}$ ).

The Journal of Antibiotics (2013) 66, 311-317; doi:10.1038/ja.2013.17; published online 17 April 2013

Keywords: chemical screening; endophytic actinomycete; hemolysis inhibitor; Polymorphospora rubra; trehangelins

\section{INTRODUCTION}

We have isolated many rare actinomycete strains from the roots of plants over the past few years and discovered a new genus and several new species of actinomycetes. ${ }^{1-5}$ To enable the discovery of new compounds from the cultured broth of the endophytic actinomycete isolates, we have exploited biological screening programs, looking for antibacterial, antifungal, cytotoxic and antiprotozoal activities, as well as a chemical screening approach using LC/UV and a LC/MS/MS system. During the course of chemical screening, new compounds possessing antitrypanosomal activity, namely spoxazomicins A-C, were discovered using Dragendorff's reagent from the cultured broth of Streptosporangium oxazolinicum K07-0460 ${ }^{\mathrm{T}}{ }^{6}$ Further research using LC/UV and LC/MS has identified compounds with unique UV and MS spectra, isolated from the cultured broth of an endophytic actinomycete strain, Polymorphospora rubra K07-0510. The new compounds, designated trehangelins A (1), B (2) and C (3), were isolated and the structures were elucidated (Figure 1). The trehangelins showed potent inhibitory activity against hemolysis of red blood cells (RBCs) induced by light-activated pheophorbide $a$.

This report details the taxonomy of the producing strain, fermentation, isolation, physico-chemical properties, structural elucidation and some biological activities of the compounds 1, 2 and 3.

\section{RESULTS}

Taxonomy of the producing strain, Polymorphospora rubra K07-0510

Strain K07-0510 was isolated from the roots of a plant, a variety of orchid, collected on Iriomote Island, Okinawa, Japan. The strain grew well on yeast extract-malt extract agar, inorganic salts-starch agar and tyrosine agar but did not grow on oatmeal agar, glucose-nitrate agar or glucose-peptone agar. The colony color was reddish orange. Aerial mycelia were produced on GPM agar (glucose $1.0 \%$, peptone $0.5 \%$, meat extract $0.5 \%, \mathrm{NaCl} 0.3 \%$, agar $1.2 \%, \mathrm{pH} 7.0$ ) of the test media, and the aerial mass color was white. Short spore chains were formed, and the spores with the smooth surface were cylindrical in shape, $0.7 \sim 1.1 \mu \mathrm{m}$ long $\times 0.5 \sim 1.0 \mu \mathrm{m}$ wide in size (Figure 2 ). No soluble pigment was produced. Whole-cell hydrolysates contained meso-DAP (diaminopimelic acid). The predominant menaquinones of the strain were MK-10 $\left(\mathrm{H}_{6}\right)$ and MK-9 $\left(\mathrm{H}_{6}\right)$, whereas MK-10 $\left(\mathrm{H}_{8}\right)$, MK-10 $\left(\mathrm{H}_{4}\right)$, MK-9 $\left(\mathrm{H}_{8}\right)$ and MK-9 $\left(\mathrm{H}_{4}\right)$ were detected as minor menaquinones. The 16S rRNA gene sequence (1200 nucleotides) was determined and analyzed using the EzTaxon-e database (http:// eztaxon-e.ezbiocloud.net/). The result indicated that the strain K070510 is closest to Polymorphospora rubra TT97-42 ${ }^{\mathrm{T}}$ (AB223089, similarity; 99.9\%), which is the only valid species in the genus Polymorphospora. ${ }^{7}$ On the basis of the morphological and cultural

\footnotetext{
${ }^{1}$ Research Organization for Infection Control Sciences, Kitasato University, Tokyo, Japan; ${ }^{2}$ Graduate School of Infection Control Sciences, Kitasato University, Tokyo, Japan and ${ }^{3}$ Kitasato Institute for Life Sciences, Kitasato University, Tokyo, Japan

Correspondence: Dr T Nakashima, Research Organization for Infection Control Sciences, Kitasato University, 5-9-1 Shirokane, Minato-ku, Tokyo 108-8641, Japan.

E-mail: takuji@lisci.kitasato-u.ac.jp

or Professor Y Takahashi, Kitasato Institute for Life Sciences, Kitasato University, 5-9-1 Shirokane, Minato-ku, Tokyo 108-8641, Japan.

E-mail: ytakaha@lisci.kitasato-u.ac.jp

Received 18 October 2012; revised 27 January 2013; accepted 4 February 2013; published online 17 April 2013
} 




Trehangelin A (1)

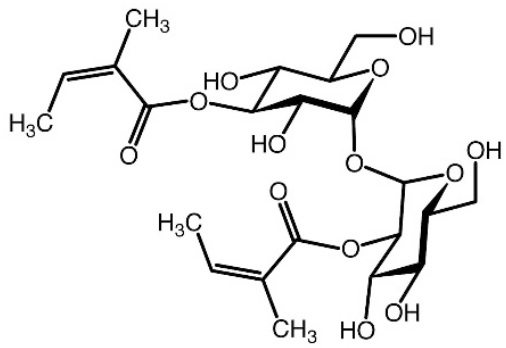

Trehangelin B (2)

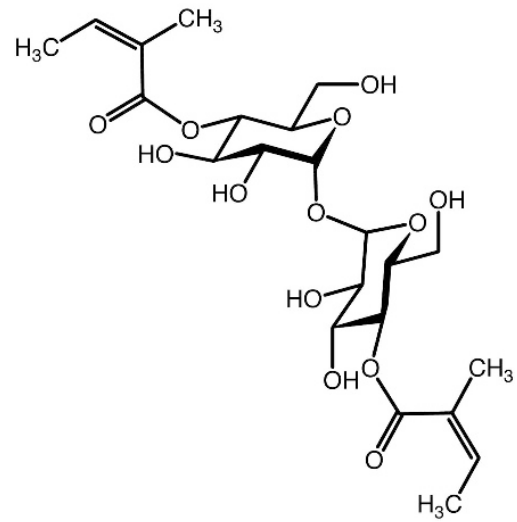

Trehangelin C (3)

Figure 1 Structures of trehangelins $A, B$ and $C$ isolated from a cultured broth of strain K07-0510.

properties and $16 \mathrm{~S}$ rRNA gene sequence similarity, strain K07-0510 is identified as P. rubra.

Isolation of the bioactive compounds

The procedure for isolation of compounds 1, 2 and 3 is summarized in Scheme 1. The 9-day old cultured broth (1.81) was added to an equal amount of ethanol and then filtered. The filtrate was concentrated under reduced pressure to remove ethanol and the aqueous solution was extracted three times with ethyl acetate (total volume of $1.81)$. The organic layer was concentrated under reduced pressure to yield a crude material $(662 \mathrm{mg})$. The ethyl acetate extract was applied to silica gel column chromatography that was eluted with each $500 \mathrm{ml}$ of a mixture of $\mathrm{CHCl}_{3}-\mathrm{MeOH}(100: 0,100: 1,50: 1,10: 1,1: 1,0: 100)$ in this order. The $\mathrm{CHCl}_{3}-\mathrm{MeOH}(10: 1$ and 1:1) fractions $(470.0 \mathrm{mg})$ were applied to an octadecylsilyl silica gel (ODS) column

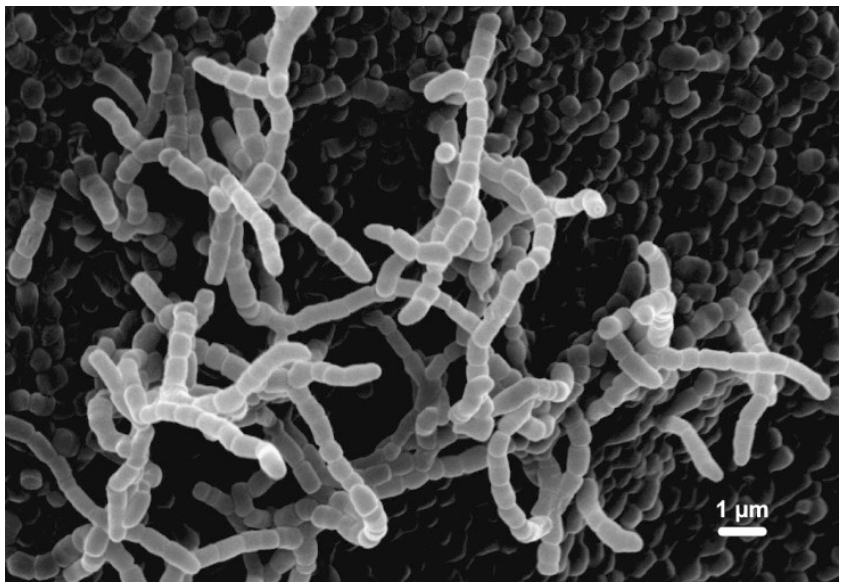

Figure 2 Scanning electron micrograph of strain K07-0510 grown on GPM agar at $27^{\circ} \mathrm{C}$ for 2 weeks.

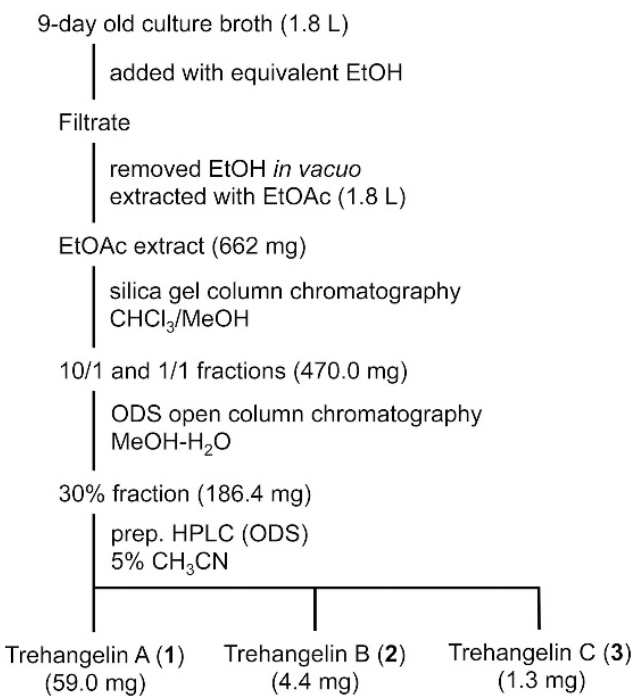

Scheme 1 Purification of trehangelins A (1), B (2) and C (3).

chromatography, which was eluted with $100 \mathrm{ml}$ each of 20,30 and $100 \% \mathrm{MeOH}$. Trehangelins B (2, r.t. $=16 \mathrm{~min}, 4.4 \mathrm{mg})$, C (3, r.t. $=$ $17 \mathrm{~min}, 1.3 \mathrm{mg}$ ) and $\mathrm{A}(1$, r.t. $=18 \mathrm{~min}, 59.0 \mathrm{mg})$ were isolated, each as a yellowish white powder, by HPLC (Inertsil ODS-4, 10 i.d. $\times 250$ $\mathrm{mm}$ ) with $5 \% \mathrm{CH}_{3} \mathrm{CN}$ aq. (flow rate, $5.0 \mathrm{ml} \mathrm{min}^{-1}$; detection, UV $254 \mathrm{~nm}$ ) from the crude mixture of $30 \% \mathrm{MeOH}$ eluate in ODS column chromatography ( $186.4 \mathrm{mg})$.

Physico-chemical properties of trehangelins A (1), B (2) and C (3) The physico-chemical properties of compounds $\mathbf{1}, 2$ and 3 are summarized in Table 1 . They are readily soluble in $\mathrm{H}_{2} \mathrm{O}$ and $\mathrm{MeOH}$. Compounds 1, 2 and 3 showed absorption maxima at $216-218 \mathrm{~nm}$ in UV spectra. The IR absorption at $1700 \mathrm{~cm}^{-1}$ suggested the presence of carbonyl groups. The similarity in physico-chemical properties strongly suggested that these three compounds are structurally related.

\section{Structure elucidation of compound 1}

The molecular formula of $\mathbf{1}$ was elucidated by ESI-MS to be $\mathrm{C}_{22} \mathrm{H}_{34} \mathrm{O}_{13}$, requiring six degrees of unsaturation. The ${ }^{1} \mathrm{H}$ and ${ }^{13} \mathrm{C}$ 
NMR spectra data measured in $\mathrm{CD}_{3} \mathrm{OD}$ of $\mathbf{1}$ are listed in Table 2. The ${ }^{13} \mathrm{C}$ NMR and HSQC spectra indicated only 11 carbons, half the expected number, implying a symmetric structure, which were classified into one ester carbonyl carbon $\left(\delta_{\mathrm{C}} 169.6\right)$, one $s p^{2}$ quaternary carbon, one $s p^{2}$ methine carbon, five oxygenated $s p^{3}$ methine carbons, including one $s p^{3}$ anomeric carbon $\left(\delta_{\mathrm{C}} 95.1\right)$, one oxygenated $s p^{3}$ methylene carbon and two olefinic methyl carbons. In

Table 1 Physico-chemical properties of trehangelins A (1), B (2) and C (3)

\begin{tabular}{|c|c|c|c|}
\hline & 1 & 2 & 3 \\
\hline $\begin{array}{l}\text { Appearance } \\
\text { Molecular formula } \\
\text { Molecular weight }\end{array}$ & $\begin{array}{l}\text { White powder } \\
\mathrm{C}_{22} \mathrm{H}_{34} \mathrm{O}_{13} \\
506\end{array}$ & $\begin{array}{l}\text { White powder } \\
\mathrm{C}_{22} \mathrm{H}_{34} \mathrm{O}_{13} \\
506\end{array}$ & $\begin{array}{l}\text { White powder } \\
\mathrm{C}_{22} \mathrm{H}_{34} \mathrm{O}_{13} \\
506\end{array}$ \\
\hline $\begin{array}{l}\text { ESI-MS }(m / z) \\
\text { Calcd }\end{array}$ & $\begin{array}{l}507.2078 \\
\text { (for } \mathrm{C}_{22} \mathrm{H}_{35} \mathrm{O}_{13} \text { ) }\end{array}$ & $\begin{array}{l}507.2078 \\
\text { (for } \mathrm{C}_{22} \mathrm{H}_{35} \mathrm{O}_{13} \text { ) }\end{array}$ & $\begin{array}{l}507.2078 \\
\text { (for }\end{array}$ \\
\hline $\begin{array}{l}\text { Found } \\
\text { UV } \lambda_{\max }(\mathrm{MeOH}) \mathrm{nm} \\
\text { IR } v_{\max }(\mathrm{KBr}) \mathrm{cm}^{-1}\end{array}$ & $\begin{array}{l}507.2087 \\
{[\mathrm{M}+\mathrm{H}]^{+}} \\
216 \\
2360,1699 \\
1649,1458, \\
1385,1240 \\
1153,1038, \\
997,851 \\
\left.167.1^{\circ} \text { (c } 0.1\right)\end{array}$ & $\begin{array}{l}507.2074 \\
{\left[\mathrm{M}+\mathrm{H}^{+}\right.} \\
218 \\
2382,1701 \\
1649,1458, \\
1383,1243 \\
1151,1047 \\
1001,855 \\
\left.13.5^{\circ} \text { (c } 0.1\right)\end{array}$ & $\begin{array}{l}507.2074 \\
{\left[\mathrm{M}+\mathrm{H}^{+}\right.} \\
218 \\
2378,1701 \\
1649,1455 \\
1385,1236 \\
1153,1045 \\
999,858 \\
\left.11.4^{\circ} \text { (c } 0.1\right)\end{array}$ \\
\hline $\begin{array}{l}\text { Solubility } \\
\text { Soluble } \\
\text { Insoluble }\end{array}$ & $\begin{array}{l}\mathrm{H}_{2} \mathrm{O}, \mathrm{MeOH} \\
\text { Hexane, } \mathrm{CHCl}_{3}\end{array}$ & $\begin{array}{l}\mathrm{H}_{2} \mathrm{O}, \mathrm{MeOH} \\
\text { Hexane, } \mathrm{CHCl}_{3}\end{array}$ & $\begin{array}{l}\mathrm{H}_{2} \mathrm{O}, \mathrm{MeOH} \\
\text { Hexane, } \mathrm{CHCl}_{3}\end{array}$ \\
\hline
\end{tabular}

${ }^{1} \mathrm{H}-{ }^{1} \mathrm{H}$ COSY experiments, the spin systems were from $\mathrm{H}-1$ to $\mathrm{H}-5$ and from $8-\mathrm{CH}_{3}$ to $9-\mathrm{CH}_{3}$ (Figure 3). The HMBC correlations from $\mathrm{H}-1\left(\delta_{\mathrm{H}} 5.21\right)$ to $\mathrm{C}-3\left(\delta_{\mathrm{C}} 76.5\right)$ and $\mathrm{C}-5\left(\delta_{\mathrm{C}} 73.9\right)$, from $\mathrm{H}-2\left(\delta_{\mathrm{H}} 3.71\right)$ to $\mathrm{C}-4\left(\delta_{\mathrm{C}} 70.0\right)$ and from $\mathrm{H}-3\left(\delta_{\mathrm{H}} 5.48\right)$ to $\mathrm{C}-5$ indicated the linkage between $\mathrm{C}-1$ and $\mathrm{C}-5$ through an oxygen atom to form a tetrahydropyran ring. The HMBC correlations from $\mathrm{H}_{2}-6\left(\delta_{\mathrm{H}} 3.73\right.$ and $3.80)$ to $\mathrm{C}-4$ and from $\mathrm{H}-4\left(\delta_{\mathrm{H}} 3.56\right)$ to $\mathrm{C}-6\left(\delta_{\mathrm{C}} 62.2\right)$ indicated that the oxygenated $s p^{3}$ methylene carbon in 6-position was attached to C-5 to form a carbohydrate moiety. A small vicinal coupling constant was observed between $\mathrm{H}-1$ and $\mathrm{H}-2(\mathrm{~J}=3.6 \mathrm{~Hz})$, and large coupling constants were observed between $\mathrm{H}-2$ and $\mathrm{H}-3(\mathrm{~J}=10.0 \mathrm{~Hz})$, between $\mathrm{H}-3$ and $\mathrm{H}-4(J=9.6 \mathrm{~Hz})$ and between $\mathrm{H}-4$ and $\mathrm{H}-5(J=10.0 \mathrm{~Hz})$. Moreover, the ROESY correlations were observed for $\mathrm{H}-2 / \mathrm{H}-4$ and $\mathrm{H}-3 / \mathrm{H}-5$ (Figure 4). These results indicated that the carbohydrate moiety of $\mathbf{1}$ is a $\alpha$-glucopyranose. The HMBC correlations from $\mathrm{H}-1$ $\left(\delta_{\mathrm{H}} 5.21\right)$ to $\mathrm{C}-1^{\prime}\left(\delta_{\mathrm{C}} 95.1\right)$ indicated the linkage between $\mathrm{C}-1$ and $\mathrm{C}-1^{\prime}$ of two glucopyranose units through an oxygen atom to form an $\alpha, \alpha$-1,1-glycoside bond, the same as trehalose. This was supported by characteristic IR absorption at $850 \mathrm{~cm}^{-1}$ and chemical shift of anomeric carbon $\left(\delta_{\mathrm{C}} 95.1\right){ }^{8}$

The HMBC correlations from $\mathrm{H}-9\left(\delta_{\mathrm{H}} 6.11\right)$ to $8-\mathrm{CH}_{3}\left(\delta_{\mathrm{C}} 20.8\right)$, from $8-\mathrm{CH}_{3}\left(\delta_{\mathrm{H}} 1.95\right)$ to $\mathrm{C}-7\left(\delta_{\mathrm{C}} 169.9\right), \mathrm{C}-8\left(\delta_{\mathrm{C}} 129.6\right)$ and C-9 $\left(\delta_{\mathrm{C}} 138.2\right)$ and from $9-\mathrm{CH}_{3}\left(\delta_{\mathrm{H}} 2.01\right)$ to $\mathrm{C}-8$ and $\mathrm{C}-9$ (Figure 3), together with the ROESY correlations for $\mathrm{H}-9 / 8-\mathrm{CH}_{3}$ (Figure 4) indicated that $\mathbf{1}$ had an angelic acid (Z-2-methyl-2butenoic acid) moiety. Finally, the HMBC correlation from $\mathrm{H}-3$ to C-7 indicated linkage between C-3 and C-7 through an oxygen atom to form an ester bond. Therefore, the structure of $\mathbf{1}$ was elucidated as a 3,3'-diangeloyl trehalose, and $\mathbf{1}$ was designated as trehangelin A (Figure 1).

Table $2{ }^{1} \mathrm{H}-\mathrm{NMR}$ and ${ }^{13} \mathrm{C}$-NMR data of trehangelins $\mathrm{A}(1), \mathrm{B}(2)$ and $\mathrm{C}(3)$ in $\mathrm{CD}_{3} \mathrm{OD}(400 \mathrm{MHz})$

\begin{tabular}{|c|c|c|c|c|c|c|}
\hline \multirow{2}{*}{ Position } & \multicolumn{2}{|r|}{ Trehangelin A (1) } & \multicolumn{2}{|r|}{ Trehangelin B (2) } & \multicolumn{2}{|r|}{ Trehangelin C (3) } \\
\hline & $\delta_{C}$ & $\delta_{H}$ (int., mult., $\mathrm{J}$ in $\mathrm{Hz}$ ) & $\delta_{C}$ & $\delta_{H}$ (int., mult., $J$ in $H z$ ) & $\delta_{C}$ & $\delta_{H}$ (int., mult., $J$ in $\mathrm{Hz}$ ) \\
\hline 1 & 95.1 & $5.21(1 \mathrm{H}, \mathrm{d}, 3.6)$ & 95.6 & $5.16(1 \mathrm{H}, \mathrm{d}, 3.6)$ & 95.1 & $5.20(1 \mathrm{H}, \mathrm{d}, 4.0)$ \\
\hline 2 & 71.6 & $3.71(1 \mathrm{H}, \mathrm{dd}, 3.6,10.0)$ & 71.5 & $3.68(1 \mathrm{H}, \mathrm{dd}, 3.6,10.0)$ & 73.4 & $3.61(1 \mathrm{H}, \mathrm{dd}, 4.0,10.0)$ \\
\hline 3 & 76.5 & $5.48(1 \mathrm{H}, \mathrm{dd}, 9.6,10.0)$ & 76.4 & $5.30(1 \mathrm{H}, \mathrm{dd}, 8.8,10.0)$ & 72.3 & $4.02(1 \mathrm{H}, \mathrm{dd}, 9.6,10.0)$ \\
\hline 4 & 70.0 & $3.56(1 \mathrm{H}, \mathrm{dd}, 9.6,10.0)$ & 69.0 & $3.64(1 \mathrm{H}, \mathrm{dd}, 8.8,10.0)$ & 72.4 & $4.91(1 \mathrm{H}, \mathrm{dd}, 9.6,10.0)$ \\
\hline 5 & 73.9 & $3.92(1 \mathrm{H}, \mathrm{ddd}, 2.4,4.8,10.0)$ & 74.0 & $3.59(1 \mathrm{H}, \mathrm{m})$ & 72.0 & $4.07(1 \mathrm{H}, \mathrm{ddd}, 2.4,4.8,10.0)$ \\
\hline 6 & 62.2 & $\begin{array}{l}3.73(1 \mathrm{H}, \mathrm{m}) \\
3.80(1 \mathrm{H}, \mathrm{dd}, 2.4,12.0)\end{array}$ & 61.6 & $\begin{array}{l}3.60(1 \mathrm{H}, \mathrm{m}) \\
3.67(1 \mathrm{H}, \mathrm{dd}, 2.4,12.0)\end{array}$ & 62.3 & $\begin{array}{l}3.51(1 \mathrm{H}, \mathrm{m}) \\
3.59(1 \mathrm{H}, \mathrm{dd}, 2.4,12.4)\end{array}$ \\
\hline 7 & 169.6 & & 169.6 & & 168.8 & \\
\hline 8 & 129.6 & & 129.6 & & 129.0 & \\
\hline 9 & 138.2 & $6.11(1 \mathrm{H}, \mathrm{qq}, 1.2,7.2)$ & 138.5 & $6.12(1 \mathrm{H}, \mathrm{qq}, 1.6,7.2)$ & 139.5 & $6.15(1 \mathrm{H}, \mathrm{qq}, 1.2,7.2)$ \\
\hline 8-Me & 20.8 & $1.95(3 \mathrm{H}, \mathrm{dq}, 1.2,1.2)$ & 20.8 & $1.94(3 \mathrm{H}, \mathrm{dq}, 1.6,1.6)$ & 20.7 & $1.91(3 \mathrm{H}, \mathrm{dq}, 1.2,1.2)$ \\
\hline 9-Me & 16.0 & $2.01(3 \mathrm{H}, \mathrm{qd}, 1.2,7.2)$ & 16.0 & $2.00(3 \mathrm{H}, \mathrm{qd}, 1.6,7.2)$ & 16.1 & $1.99(3 \mathrm{H}, \mathrm{qd}, 1.2,7.2)$ \\
\hline $1^{\prime}$ & & & 92.8 & $5.37(1 \mathrm{H}, \mathrm{d}, 4.0)$ & & \\
\hline $2^{\prime}$ & & & 74.3 & $4.76(1 \mathrm{H}, \mathrm{dd}, 4.0,10.0)$ & & \\
\hline $3^{\prime}$ & & & 72.0 & $4.13(1 \mathrm{H}, \mathrm{dd}, 8.8,10.0)$ & & \\
\hline $4^{\prime}$ & & & 72.1 & $3.44(1 \mathrm{H}, \mathrm{dd}, 8.8,10.0)$ & & \\
\hline $5^{\prime}$ & & & 73.9 & $3.93(1 \mathrm{H}, \mathrm{ddd}, 2.4,5.2,10.0)$ & & \\
\hline $6^{\prime}$ & & & 62.5 & $\begin{array}{l}3.72(1 \mathrm{H}, \mathrm{dd}, 5.2,12.0) \\
3.82(\mathrm{dd}, 2.4,12.0)\end{array}$ & & \\
\hline $7^{\prime}$ & & & 168.8 & & & \\
\hline $8^{\prime}$ & & & 128.5 & & & \\
\hline $9^{\prime}$ & & & 141.2 & $6.22(1 \mathrm{H}, \mathrm{qq}, 1.6,7.2)$ & & \\
\hline $8^{\prime}-\mathrm{Me}$ & & & 20.9 & $1.96(3 \mathrm{H}, \mathrm{dq}, 1.6,1.6)$ & & \\
\hline $9^{\prime}-\mathrm{Me}$ & & & 16.5 & $2.08(3 \mathrm{H}, \mathrm{qd}, 1.6,7.2)$ & & \\
\hline
\end{tabular}



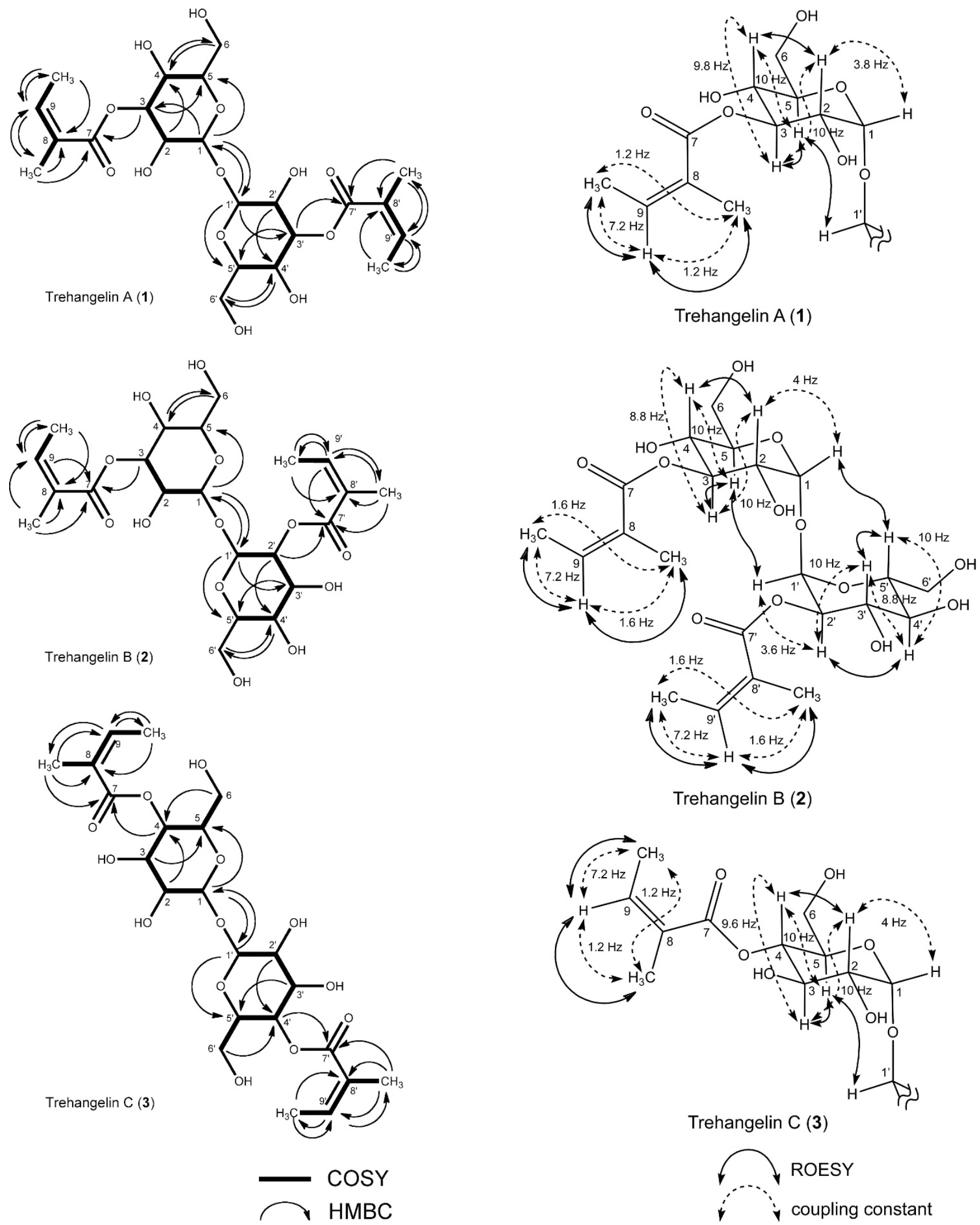

Trehangelin B (2)

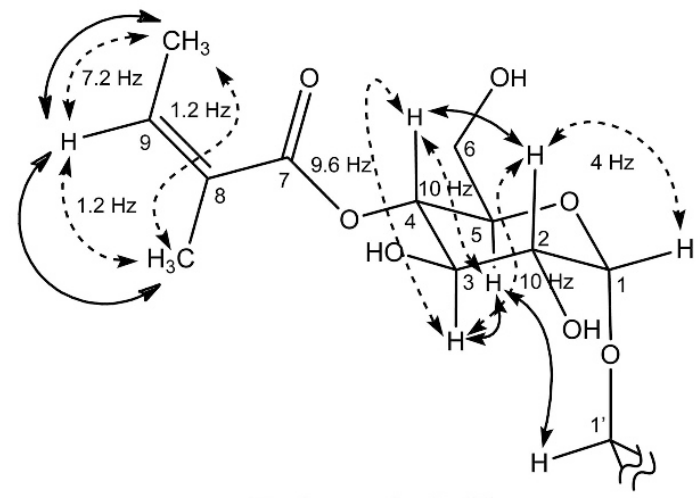

Trehangelin C (3)

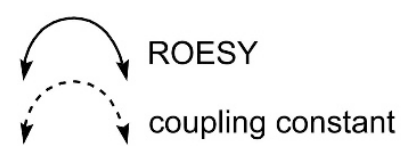

Figure $3 \mathrm{COSY}$ and HMBC correlations of trehangelins A (1), B (2) and C (3).

Figure 4 Relative configuration of trehangelins A (1), B (2) and C (3). 


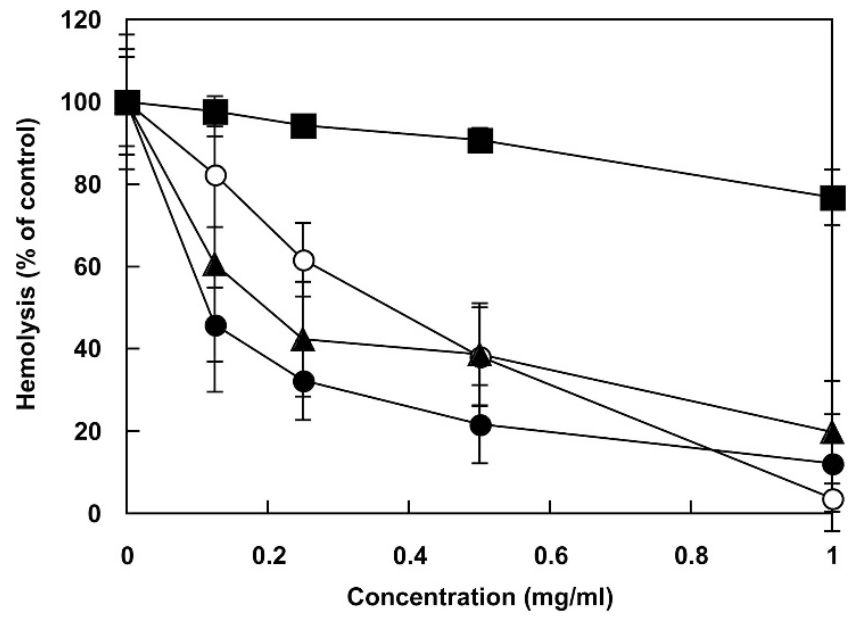

Figure 5 Inhibitory effects of trehangelins $A, B$ and $C$ on hemolysis of red blood cells by light-activated pheophorbide a. $\boldsymbol{O}$, trehangelin $A$; $\mathbf{\square}$, trehangelin $\mathrm{B} ; \boldsymbol{\Delta}$, trehangelin $\mathrm{C}$; $\bigcirc$, ascorbic acid.

The absolute stereochemistry of the trehalose moiety of 1 was determined as described in the following. The trehalose purified from hydrolysate by the treatment of hydrazine hydrate was identified as D- $(+)$-trehalose ( $\alpha$-D-glucopyranosyl- $(1 \rightarrow 1)$ - $\alpha$-D-glucopyranoside) by ${ }^{1} \mathrm{H}$ NMR spectra; $\delta_{\mathrm{H}} 5.15(\mathrm{~d}, 2 \mathrm{H}, J 4.0 \mathrm{~Hz}), \delta_{\mathrm{H}} 3.85-3.72(\mathrm{~m}, 8 \mathrm{H}), \delta_{\mathrm{H}}$ $3.61(\mathrm{dd}, 2 \mathrm{H}, J 4.0,10.0 \mathrm{~Hz})$, and $\delta_{\mathrm{H}} 3.41(\mathrm{t}, 2 \mathrm{H}, J 9.2 \mathrm{~Hz})$, ESI-MS; calcd for $\mathrm{C}_{12} \mathrm{H}_{22} \mathrm{O}_{11} \mathrm{Na}[\mathrm{M}+\mathrm{Na}]^{+} 365.1060$, found $[\mathrm{M}+\mathrm{Na}]^{+}$ 365.1034, and optical rotation; $[\alpha]_{\mathrm{D}}^{27}=+170.8\left(c=1, \mathrm{H}_{2} \mathrm{O}\right){ }^{9}$

\section{Structure elucidation of compound 2}

The molecular formula of 2 was elucidated by ESI-MS to be $\mathrm{C}_{22} \mathrm{H}_{34} \mathrm{O}_{13}$ and identical to that of 1 . The ${ }^{1} \mathrm{H}$ and ${ }^{13} \mathrm{C}$ NMR spectra data measured in $\mathrm{CD}_{3} \mathrm{OD}$ of 2 are listed in Table 2 and they were similar to those of 1 . The ${ }^{13} \mathrm{C} N M R$ and HSQC spectra showed 22 carbons, which indicated that the structure of 2 was asymmetric. Although the chemical shifts at $\mathrm{H}-2\left(\delta_{\mathrm{H}} 3.68\right)$ and $\mathrm{H}-3\left(\delta_{\mathrm{H}} 5.30\right)$ in 2 were almost the same as the chemical shifts at $\mathrm{H}-2\left(\delta_{\mathrm{H}} 3.71\right)$ and $\mathrm{H}-3$ $\left(\delta_{\mathrm{H}} 5.48\right)$ in 1 , the chemical shifts of $\mathrm{H}-2^{\prime}\left(\delta_{\mathrm{H}} 4.76\right)$ and $\mathrm{H}-3^{\prime}\left(\delta_{\mathrm{H}}\right.$ $4.13)$ in 2 were actually different from those of 1 . The HMBC correlations from $\mathrm{H}-3\left(\delta_{\mathrm{H}} 5.30\right)$ to $\mathrm{C}-7\left(\delta_{\mathrm{C}} 169.6\right)$ and $\mathrm{H}-2^{\prime}\left(\delta_{\mathrm{H}} 4.76\right)$ to $\mathrm{C}-7^{\prime}\left(\delta_{\mathrm{C}}\right.$ 168.8) indicated linkage of C-3 and C-7 through an oxygen atom and C-2' and C-7' through an oxygen atom to form ester bonds (Figure 3). Therefore, the structure of 2 was elucidated as a 3,2'diangeloyl trehalose, and 2 was designated as trehangelin B (Figure 1).

\section{Structure elucidation of compound 3}

The molecular formula of $\mathbf{3}$ was elucidated by ESI-MS to be $\mathrm{C}_{22} \mathrm{H}_{34} \mathrm{O}_{13}$ and similar to that of 1 . The ${ }^{1} \mathrm{H}$ and ${ }^{13} \mathrm{C}$ NMR spectra data measured in $\mathrm{CD}_{3} \mathrm{OD}$ of 3 are listed in Table 2 and they were similar to those of $\mathbf{1}$. The ${ }^{13} \mathrm{C}$ NMR and HSQC spectra identified only 11 carbons, which indicated that the structure of 3 was symmetric. However, the H-3 $\left(\delta_{\mathrm{H}} 5.48\right)$ and $\mathrm{H}-4\left(\delta_{\mathrm{H}} 3.56\right)$ in 1 were shifted at $\mathrm{H}-3\left(\delta_{\mathrm{H}} 4.02\right)$ and $\mathrm{H}-4\left(\delta_{\mathrm{H}} 4.91\right)$ in 3 , respectively. The HMBC correlation from $\mathrm{H}-4\left(\delta_{\mathrm{H}} 4.91\right)$ to $\mathrm{C}-7\left(\delta_{\mathrm{C}} 168.8\right)$ indicated linkage of C-4 and C-7 through an oxygen atom to form an ester bond (Figure 3). Therefore, the structure of 3 was elucidated as a $4,4^{\prime}$ diangeloyl trehalose, and 3 was designated as trehangelin C (Figure 1).
Table 3 Cytotoxic activities of trehangelins A, B and C against several human cell lines

\begin{tabular}{lccc}
\hline Cell lines & Trehangelin A & Trehangelin B & Trehangelin C \\
\hline HEK-293FT & $99.5 \pm 3.4$ & $93.0 \pm 0.9$ & $95.7 \pm 15.6$ \\
Panc-1 & $100.8 \pm 9.1$ & $86.6 \pm 1.5$ & $100.5 \pm 0.8$ \\
NCl-H1299 & $95.6 \pm 11.0$ & $93.2 \pm 3.7$ & $96.5 \pm 1.2$ \\
HT-29 & $106.3 \pm 38.4$ & $98.9 \pm 5.6$ & $97.7 \pm 2.3$ \\
\hline
\end{tabular}

Percentage of control treated with dimethyl sulfoxide.

\section{Biological activities}

The inhibitory effects of compounds $\mathbf{1}, \mathbf{2}$ and $\mathbf{3}$ on the hemolysis of RBCs induced by light-activated pheophorbide $a$ were evaluated. All three compounds had no effect on RBCs under dark at a final concentration of $1 \mathrm{mg} \mathrm{ml}^{-1}$. However, as shown in Figure 5, compounds 1, 2 and 3 showed inhibitory activity against the hemolysis in a concentration-dependent manner, and the $\mathrm{IC}_{50}$ values of compound 1,2 and 3 were estimated to be $0.1 \mathrm{mg} \mathrm{ml}^{-1}(0.2 \mathrm{~mm}),>1 \mathrm{mg} \mathrm{ml}^{-1}$ ( $>2 \mathrm{~mm}$ ) and $0.4 \mathrm{mg} \mathrm{ml}^{-1}(0.8 \mathrm{~mm})$, respectively. The compounds 1 and 3 , those with a symmetric structure, showed more potent inhibitory activities than that of ascorbic acid ( $\mathrm{IC}_{50}$ value, $0.4 \mathrm{mg} \mathrm{ml}^{-1}(2.3 \mathrm{~mm})$ ), but compound 2, which has an asymmetric structure, showed only slight inhibitory activity. On the other hand, no significant cytotoxic activities of compounds 1, 2 and 3 against the several cell lines were observed even at $100 \mu \mathrm{g} \mathrm{ml}^{-1}$ (Table 3).

\section{DISCUSSION}

A endophytic rare actinomycete stain, P. rubra K07-0510, was isolated from roots of an orchid. This strain produced three new compounds 1, 2 and 3. All the three compounds consisted of a trehalose moiety and two angelic acid moieties.

Trehalose was first found from an ergot of rye by Wiggers in $1832 .{ }^{10}$ Trehalose is known to be one of the sources of energy in many living organisms and can be found in many organisms, including bacteria, fungi, insects, plants and invertebrates. Trehalose has protective activity against various natural stresses, such as dryness, freezing and osmopressure. Recently, it was reported that trehalose was capable of suppressing degradation of fatty acid by heat oxidation. ${ }^{11}$ The protective effect of trehalose on heat oxidation of linoleic acid was demonstrated to be an interaction between the positions 3 and 6 of trehalose molecules and the positions 9, 10, 12 and 13 on olefin residue of the linoleic acid molecule, using NMR analysis. The results suggest that the interaction with trehalose stabilizes the olefin residue of linoleic acid against heat oxidation.

In our study, the inhibitory effects of compounds $\mathbf{1 , 2}$ and 3 on the hemolysis of RBCs induced by light-activated pheophorbide $a$ were investigated. It is known that pheophorbide $a$ activated with light leads to the production of a singlet oxygen and that cells suffer damage through oxidation of the cell membrane. ${ }^{12,13}$ Compounds $\mathbf{1}$, 2 and 3 demonstrated inhibitory activity against the hemolysis of RBCs induced by light-activated pheophorbide $a$. If this inhibitory effect of these compounds is the same as the inhibitory action of trehalose against the heat oxidation of linoleic acid, it is considered that the compound 1, which contains two angelic acid moieties at 3 and $3^{\prime}$ positions of trehalose, should have decreased activity compared with compounds 2 or 3 , which have two angelic acid moieties at position 2, 3 or 4 . However, compound $\mathbf{1}$ had more potent inhibitory activity than compounds 2 and 3 . Therefore, the inhibitory action of trehangelins on the hemolysis of RBCs induced by light- 
activated pheophorbide $a$ may occur via a different mechanism than the mode of action of trehalose on the heat oxidation of linoleic acid.

Furthermore, the symmetric compounds $\mathbf{1}$ and $\mathbf{3}$ showed more potent activities than the asymmetric compound 2 . Therefore, the positions of angelic acids bound to a trehalose molecule and the structural symmetry may be important for the hemolysis inhibition of RBCs induced by light-activated pheophorbide $a$.

Angelic acid is isolated from plants such as Alkanna tinctoria, ${ }^{14}$ carrots $^{15}$ or Euphorbia species. ${ }^{16}$ In addition, angelic acid esters included in Roman chamomile, a popular herb, are used as an aromatherapy essential oil. It is known that angelic acid esters are especially oriented towards mood and the psyche, with cephalic and psychotropic characteristics. ${ }^{17}$ Thus, compounds 1, 2 and 3, consisting of trehalose and angelic acid, may have many other uses. In addition, we are particularly interested in knowing whether there is any physiological effects of these compounds produced by an endophytic actinomycete strain, P. rubra K07-0510, on the plants they are associated with. To our knowledge, this is the first report of the metabolites produced by the genus Polymorphospora.

\section{METHODS}

\section{General experiments}

All solvents (EtOAc, $\mathrm{CHCl}_{3}$, EtOH, $\mathrm{MeOH}$ and $\mathrm{CH}_{3} \mathrm{CN}$ ) were purchased from Kanto Chemical (Tokyo, Japan). Silica gel and Pegasil ODS were purchased from Merck (Darmstadt, Germany) and Senshu Scientific Co. (Tokyo, Japan), respectively. The Inertsil ODS-4 column was obtained from GL Science Inc. (Tokyo, Japan).

NMR spectra were measured in $\mathrm{CD}_{3} \mathrm{OD}$ using a Varian XL-400 spectrometer (Varian, Palo Alto, CA, USA). Chemical shifts were expressed in p.p.m. and were referenced to $\mathrm{CD}_{3} \mathrm{OD}$ (3.31 p.p.m.) in the ${ }^{1} \mathrm{H}$ NMR spectra and to $\mathrm{CD}_{3} \mathrm{OD}$ (49.0 p.p.m.) in the ${ }^{13} \mathrm{C}$ NMR spectra. ESI-MS spectra were measured on a QSTAR Elite Hybrid MS/MS spectrometer (AB Sciex Co., MA, USA). IR spectra $(\mathrm{KBr})$ were taken on a Horiba FT-210 Fourier transform IR spectrometer (Horiba Ltd, Kyoto, Japan). UV spectra were measured with a Hitachi U-2810 spectrophotometer (Hitachi, Tokyo, Japan). Optical rotation was measured on a JASCO model DIP-181 polarimeter (JASCO Co., Tokyo, Japan).

\section{Taxonomic studies}

The International Streptomyces Project media recommended by Shirling and Gottlieb $^{18}$ and media recommended by Waksman ${ }^{19}$ were used to investigate cultural characteristics. Cultures were observed after incubation for 3 weeks at $27^{\circ} \mathrm{C}$. The morphological characteristics were observed by scanning electron microscope (JSM-5600, JEOL, Tokyo, Japan) after incubation on GPM agar for 2 weeks at $27^{\circ} \mathrm{C}$ and fixation with $4 \%$ osmium tetroxide vapor. Isomers of DAP in whole-cell hydrolysates were determined by TLC, following the standard methods of Becker et al. ${ }^{20}$ and Hasegawa et al. ${ }^{21}$ Menaquinones were extracted and purified by the method of Collins et al.,22 then analyzed by LC/MS (JSM-T 100LP, JEOL) with a CAPCELL PAK C18 column (Shiseido, Tokyo, Japan) eluted with methanol/2-propanol (7:3). 16S rRNA gene sequence was amplified by PCR and sequenced on a DNA sequencer (Applied Biosystems 3130 Genetic Analyzer, Applied Biosystems, Foster, CA, USA) using a BigDye Terminator v3.1 cycle sequencing kit (Applied Biosystems), according to the manufacturer's instructions.

\section{Fermentation}

Strain K07-0510 was grown and maintained on agar slants consisting of $1.0 \%$ starch, $0.3 \% \mathrm{NZ}$ amine, $0.1 \%$ yeast extract, $0.1 \%$ meat extract, $1.2 \%$ agar and $0.3 \% \mathrm{CaCO}_{3}$. A loop of spores of strain $\mathrm{K} 07-0510$ was inoculated into $100 \mathrm{ml}$ of seed medium, consisting of $2.4 \%$ starch, $0.1 \%$ glucose, $0.3 \%$ peptone, $0.3 \%$ meat extract, $0.5 \%$ yeast extract and $0.4 \% \mathrm{CaCO}_{3}$ (adjusted to $\mathrm{pH} 7.0$ before sterilization) in a 500-ml Erlenmeyer flask. The flask was incubated on a rotary shaker (210 r.p.m.) at $27^{\circ} \mathrm{C}$ for 3 days. A 1-ml portion of the seed culture was transferred to $500-\mathrm{ml}$ Erlenmeyer flasks (total 181), each containing $100 \mathrm{ml}$ of production medium, consisting of $2.0 \%$ soluble starch, $0.5 \%$ glycerol, $1.0 \%$ defatted wheat germ, $0.3 \%$ Ehlrich meat extract from Katsuwonus pelamis (Kyokuto Pharmaceutical, Inc., Tokyo, Japan), $0.3 \%$ dry yeast, $0.3 \% \mathrm{CaCO}_{3}$ (adjusted to $\mathrm{pH} 7.0$ before sterilization) and fermentation was carried out on a rotary shaker ( 210 r.p.m.) at $27^{\circ} \mathrm{C}$ for 9 days.

\section{Hydrazinolysis of trehangelin A (1)}

Hydrazinolysis of the peripheral ester groups of compound 1 was performed for the determination of an absolute configuration of trehalose. ${ }^{23}$ Compound 1 $(30 \mathrm{mg})$ in $\mathrm{MeOH}(3 \mathrm{ml})$ was treated with hydrazine hydrate $(3 \mathrm{ml})$ for $72 \mathrm{~h}$. The reaction mixture was concentrated by evaporation under vacuum, and trehalose was separated by partition between $\mathrm{H}_{2} \mathrm{O}$ and $\mathrm{CHCl}_{3}$ (each $3 \mathrm{ml}$ ). Trehalose $\left(16.5 \mathrm{mg}\right.$ ) was obtained from the $\mathrm{H}_{2} \mathrm{O}$ layer. Parts of trehalose were dissolved in $\mathrm{D}_{2} \mathrm{O}$ for measurement of ${ }^{1} \mathrm{H}$ NMR spectroscopy, in $\mathrm{H}_{2} \mathrm{O}$ for optical rotation and in $\mathrm{MeOH}$ for MS spectrometry.

\section{Biological assays}

The inhibitory activities of compounds 1, 2 and $\mathbf{3}$ against photo-oxidative hemolysis of RBCs induced by light-activated pheophorbide $a$ were measured in vitro. In addition, cytotoxic activities of compounds 1, 2 and 3 were evaluated.

Hemolytic assay: The hemolysis of RBCs induced by light-activated pheophorbide $a$ was measured by a modified method of light irradiation system as previously described. ${ }^{12}$ Rabbit RBCs were obtained from Nippon Bio-Supply Center (Tokyo, Japan) and used within 7 days. The RBCs were washed three times with sterile phosphate-buffered saline (PBS) and made to a final concentration of $5 \%(\mathrm{v} / \mathrm{v})$ in PBS. For the hemolysis inhibition assay, $20 \mu \mathrm{l}$ aliquots of sample in PBS (at a final concentration of 0, 0.125, 0.25, 0.5, and $1 \mathrm{mg} \mathrm{ml}^{-1}$ ) and the $100 \mu \mathrm{l}$ of $5 \%(\mathrm{v} / \mathrm{v})$ suspension of RBCs in PBS were added (in triplicate) to the wells of round-bottom 96-well microplates (Corning Inc., Corning, NY, USA). After incubation for $5 \mathrm{~min}$ at $37^{\circ} \mathrm{C}$, the reaction was initiated by the addition of $80 \mu \mathrm{l}$ pheophorbide $a$ (at a final concentration of $5 \mu \mathrm{M}$ ). The plate was illuminated for $30 \mathrm{~min}$ under a light from an Eye Lamp (PRS500W, Iwasaki Electric Co., Ltd, Tokyo, Japan) or placed in the dark. In addition, a clear plastic water container was put between the lamp and the plate with the RBCs to prevent any temperature increase. After illumination, the RBCs were centrifuged at $900 \mathrm{~g}$ for $10 \mathrm{~min}$. A $100 \mu \mathrm{l}$ of each supernatant was transferred to a flat-bottom microplate (Corning Inc.). Hemolysis was determined by measuring the absorbance at $570 \mathrm{~nm}$, which is due to hemoglobin released from RBCs, using a microplate reader (model ELx 808, BioTek Instruments, Inc., Winooski, VT, USA).

Cell viability assay: Cell viabilities of compounds 1, 2 and 3 were measured by Cell Counting Kit-8 (Dojindo Laboratories, Kumamoto, Japan) in four different cell lines, namely HEK-293FT (human embryonic kidney cell line), Panc-1 (human pancreatic cancer cell line), NCI-H1299 (human non-small cell lung carcinoma cell line) and HT-29 (human colon carcinoma cell line). Briefly, $2 \times 10^{4}$ cells were seeded in 96-well plates and cultured in Dulbecco's modified Eagle's medium (Wako Pure Chemical Industries Ltd, Osaka, Japan) supplemented with $10 \%$ fetal bovine serum at $37^{\circ} \mathrm{C}$ under $5 \% \mathrm{CO}_{2}$. After culturing overnight, compounds $\mathbf{1}, \mathbf{2}$ and $\mathbf{3}$ in dimethyl sulfoxide or dimethyl sulfoxide alone were added into each well (at final concentrations of $100 \mu \mathrm{g} \mathrm{ml}^{-1}$ ). After $48 \mathrm{~h}$ of incubation at $37^{\circ} \mathrm{C}$, WST-8 solution was added to each well and incubated at $37^{\circ} \mathrm{C}$ for $4 \mathrm{~h}$.

After mixing the microplate, the cell viability was determined by measuring the absorbance at $450 \mathrm{~nm}$. The absorbance of control cells (treated with $0.3 \%$ dimethyl sulfoxide) was considered as $100 \%$. The rate of cell growth inhibition was calculated using the following formula: mean value of ((control group treated group)/control group) $\times 100 \%$. The effect of each concentration was determined in duplicate.

\section{ACKNOWLEDGEMENTS}

This work was supported, in part, by funds from Quality Assurance Flamework of Higher Education from the Ministry of Education, Culture, Sports, Sciences and Technology (MEXT), Japan. We are grateful to Mr Toru Kimura in our laboratory for his technical assistance, Ms Noriko Sato of Kitasato University for measurements of NMR spectra and Dr Tomoyasu Hirose for advice on the structure. 
1 Inahashi, Y., Matsumoto, A., Danbara, H., Ōmura, S. \& Takahashi, Y. Phytohabitans suffuscus gen. nov., sp. nov., an actinomycete of the family Micromonosporaceae isolated from plant roots. Int. J. Syst. Evol. Microbiol. 60, 2652-2658 (2010).

2 Inahashi, Y., Matsumoto, A., Ōmura, S. \& Takahashi, Y. Streptosporangium oxazolinicum sp. nov., a novel endophytic actinomycete producing new antitrypanosomal antibiotics, spoxazomicins. J. Antibiot. 64, 297-302 (2011).

3 Matsumoto, A., Fukuda, A., Inahashi, Y., Ōmura, S. \& Takahashi, Y. Actinoallomurus radicium sp. nov., isolated from the roots of two plant species. Int. J. Syst. Evol. Microbiol. 62, 295-298 (2012).

4 Inahashi, Y., Matsumoto, A., Ōmura, S. \& Takahashi, Y. Phytohabitans flavus sp, nov., Phytohabitans rumicis sp. nov. and Phytohabitans houttuyneae sp. nov., isolated from plant roots and emended description of the genus Phytohabitans. Int. J. Syst. Evol. Microbiol. 62, 2717-2723 (2012).

5 Koyama, R., Matsumoto, A., Inahashi, Y., Ōmura, S. \& Takahashi, Y. Isolation of actinomycetes from the root of the plant, Ophiopogon japonicus, and proposal of two new species, Actinoallomurus liliacearum sp. nov. and Actinoallomurus vinaceus sp. nov. J. Antibiot. 65, 335-340 (2012).

6 Inahashi, Y. et al. Spoxazomicins A-C, novel antitrypanosomal alkaloids produced by an endophytic actinomycete, Streptosporangium oxazolinicum K07-0460(T). J. Antibiot. 64, 303-307 (2011).

7 Tamura, T., Hatano, K. \& Suzuku, K. A new genus of the family Micromonosporaceae, Polymorphospora gen. nov., with a description of Polymorphospora rubra sp. nov. Int. J. Syst. Evol. Microbiol. 56, 1959-1964 (2006).

8 Roën, A., Padrón, J. I. \& Vázquez, J. T. Hydroxymethyl rotamer populations in disaccharides. J. Org. Chem. 68, 4615-4630 (2003).

9 Seo, S. K., McClintock, M. L. \& Wei, A. Cryoprotection with L- and meso-trehalose: stereochemical implications. Chembiochem. 7, 1959-1964 (2006).

10 Wiggers, H. A. L. Untersuchung über das Mutterkorn, Secale cornutum. Ann. Pharm. 1 , 129-182 (1832) in German.

11 Higashiyama, T. Novel functions and applications of trehalose. Pure Appl. Chem. 74 1263-1269 (2002)
12 Kimura, S. \& Takahashi, Y. Preventive effects of L-ascorbic acid and calcium pantothenate against photosensitive actions induced by pheophorbide $a$ and hematoporphyrin. J. Nutr. Sci. Vitaminol. 27, 521-527 (1981).

13 Moan, J. \& Berg, K. The photodegradation of porphyrins in cells can be used to estimate the lifetime of singlet oxygen. Photochem. Photobiol. 53, 549-553 (1991).

14 Papageorgiou, V. P. Wound healing properties of naphthaquinone pigments from Alkanna tinctoria. Experientia 15, 1499-1501 (1978).

15 Sonobe, H., Kamps, L. R., Mazzola, E. P. \& Roach, J. A. Isolation and identification of a new conjugated carbofuran metabolite in carrots: angelic acid ester of 3-hydroxycarbofuran. J. Agric. Food Chem. 29, 1125-1129 (1981).

16 Sosath, S., Ott, H. H. \& Hecker, E. Irritant principles of the spurge family (Euphorbiaceae). XIII. Oligocyclic and macrocyclic diterpene esters from latices of some Euphorbia species utilized as source plants of honey. J. Nat. Prod. 51, 1062-1074 (1988).

17 Jennifer, P. R. in Essential Oils: A Handbook for Aromatherapy Practice 2nd edn, 145-146 (Singing Dragon, London, UK, 2012).

18 Shiring, E. B. \& Gottlieb, D. Methods for characterization of Streptomyces species. Int. J. Syst. Evol. Microbiol. 16, 313-340 (1966).

19 Waksman, S. A. (ed.) The Actinomycetes Vol. 2 (Williams and Wilkins Co., Baltimore, MD, USA, 1961).

20 Becker, B., Lechevalier, M. P. \& Lechevalier, H. A. Chemical composition of cell-wall preparation from strains of various form-genera of aerobic actinomycetes. Appl. Microbiol. 13, 236-243 (1965).

21 Hasegawa, T., Takizawa, M. \& Tanida, S. A rapid analysis for chemical grouping of aerobic actinomycetes. J. Gen. Appl. Microbiol. 29, 319-322 (1983).

22 Collins, M. D., Goodfellow, M. \& Minnikin, D. E. Distribution of menaquinones in actinomycetes and corynebacteria. J. Gen. Microbiol. 100, 221-230 (1977).

23 Rickards, R. W., Rothschild, J. M. \& Lacey, E. Structure of actinotetraose hexatiglate, a unique glucotetraose from an actinomycete bacterium. J. Antibiot. 51, 1093-1098 (1998). 